\title{
Manfaat visual keberadaan hutan kota Padang Golf Halim
}

\author{
Ray March Syahadat ${ }^{1 *}$, Priambudi Trie Putra ${ }^{1}$, \\ 1. Prodi Arsitektur Lanskap, Fakultas Teknik Sipil dan Perencanaan, Institut Sains dan Teknologi Nasional, \\ Jl. Moh. Kahfi II, Jakarta Selatan, Indonesia \\ E-mail: ray.ar@istn.ac.id
}

\begin{abstract}
Visual benefits of the existence of the Halim Golf Course urban forest. Golf course landscape is not just a game area but also a form of green open space because it is covered by vegetation. Besides comprising a game area, the golf course landscape also has a buffer area that can be categorized as an urban forest. Halim Golf Course is one of the golf courses in Jakarta which has a non-game area in the form of urban forest. Studies on the value of the visual benefits of golf courses are rarely conducted. This study aims to determine the visual benefits of urban forest of Halim Golf Course. The method used was the assessment of visual quality of golf course buffer area with the SBE method and impression evaluation with the semantic differential method. The results obtained that urban forests in the form of golf courses generally have aesthetic value (SBE>20). In general, the results of analysis can be concluded from all samples of visual points have the impression of being healthy and beneficial. In addition, urban forests that are neatly arranged and not too dense are preferred.
\end{abstract}

Keywords: aesthethic, assessment, non-game area, green open space, impression.

\section{Pendahuluan}

Permasalahan ketersediaan RTH di area perkotaan merupakan isu yang selalu menarik untuk dibahas. RTH perkotaan tidak selalu dapat berbentuk taman atau hutan kota. Dahlan (2004) menyatakan bahwa padang golf juga merupakan salah satu jenis RTH khas perkotaan. Padang golf atau golf course selama ini dianggap hanya sebagai area rekreasi khususnya bagi kalangan menengah ke atas. Padahal, padang golf tidak hanya area merupakan area permainan. Dalam sebuah kawasan padang golf juga terdapat area nonpermainan yang berfungsi sebagai area penyangga. Penataan lanskap yang menarik umumnya memanfaatkan area nonpermainan untuk meningkatkan kualitas sebuah padang golf (Sukmawijaya et al., 2019). Area penyangga padang golf sesungguhnya dapat dikategorikan sebagai hutan kota (Dahlan, 2004). Hutan kota adalah vegetasi pohon dan asosiasinya dalam suatu komunitas yang tumbuh di kota dengan bentuk jalur, menyebar, atau bergerombol dengan meniru struktur hutan alami, membentuk habitat untuk kehidupan satwa dan memberikan kesehatan, kenyamanan, dan nilai estetika bagi lingkungan (Irwan, 1997). Hutan kota seharusnya memberikan fungsi maksimal dari keberadaan tanaman serta meningkatkan kualitas lingkungan dan daya dukung kota. Salah satu manfaat hutan kota yang juga jarang disadari yaitu manfaat visual (Dahlan, 2004). Aspek visual memiliki peran dan fungsi bagi pengguna dalam memenuhi kepuasan rohani akan keindahan dalam bentuk penataan pohon dan semak (Irwan, 1997; Mattjik, 2010). Lebih lanjut, hutan kota mampu meningkatkan keindahan lingkungan serta menutupi bagian kota yang kurang baik (Dahlan, 2004).

Padang Golf Halim (PGH) berlokasi dekat dengan Bandara Halim Perdanakusuma, Jakarta Timur. PGH dimiliki oleh TNI Angkatan Udara. PGH menggunakan tema hutan di tengah kota, dengan fasilitas 18 holes di PGH I, 18 holes di PGH II, club house, restoran, green practice, dan lainnya. PGH juga beberapa kali telah mengadakan turnamen golf nasional maupun internasional. Secara fisik, kawasan PGH yang hijau dan asri secara langsung berkontribusi terhadap RTH Kota Jakarta sehingga keberadaan PGH sebagai tempat rekreasi dan olahraga juga bermanfaat bagi lingkungan sekitar. Secara tipologi kepemilikan berdasarkan Peraturan Menteri Pekerjaan Umum Nomor 05/PRT/M/2008 mengenai penyediaan dan pemanfaatan RTH di kawasan perkotaan, $\mathrm{PGH}$ termasuk dalam RTH privat. 
Lokasi sebuah lapangan golf tentunya akan memengaruhi lanskap sekitar, termasuk kawasan permukiman masyarakat. Sebagai salah satu faktor kunci dalam keberlanjutan, peran masyarakat dalam mempersepsikan manfaat visual lapangan golf berperan penting. Penelitian mengenai padang golf lebih banyak kepada pengelolaan lapangan golf sedangkan nilai manfaat sangat jarang dikaji (Dlukha et. al., 2017; Muplihudin et al., 2019; Dewi, 2014). Untuk itu penelitian ini bertujuan untuk menilai manfaat visual keberadaan hutan kota berbentuk padang golf.

\section{Metode}

Penelitian dilaksanakan di Padang Golf Halim, Jakarta Timur (Gambar 1). Nilai manfaat hutan kota pada lanskap Padang Golf Halim (PGH), berdasarkan persepsi masyarakat diukur dengan dua pendekatan. Pendekatan pertama yaitu dengan menilai kualitas visual dan pendekatan kedua dengan menilai kesan yang ditimbulkan oleh lanskap PGH. Sebanyak 12 titik visual sekitar PGH yang memiliki karakter yang berbeda diambil sebagai sampel kemudian dinilai oleh 33 responden (Gambar 2). Penilaian visual dianalisis dengan scenic beauty estimation (SBE). Penilaian kesan terhadap visual menggunakan pendekatan semantic differential dengan menggunakan lima pasang kata bipolar terkait manfaat hutan kota dalam bentuk padang golf. Adapun kelima pasang kata tersebut antara lain bermanfaat-merugikan, panas-sejuk, asri-gersang, jelek-indah, dan sehat-sakit. Analisis multidimensional scaling (MDS) dilakukan untuk memetakan kemiripan kesan pada masing-masing lanskap (Syahadat et al., 2017). Adapun formula-formula yang digunakan sebagai berikut.

$$
S B E_{x}=\left(Z_{y x}-Z_{y 0}\right) \times 100
$$

Keterangan:

SBEx = Nilai pendugaan keindahan lanskap ke-x

$Z y x=$ Nilai rata-rata $z$ lanskap ke- $x$

Zyo = Nilai rata-rata $z$ lanskap sebagai standar

$$
\bar{x}_{i j}=\frac{\sum_{i=1}^{n} x_{i f}}{n}
$$
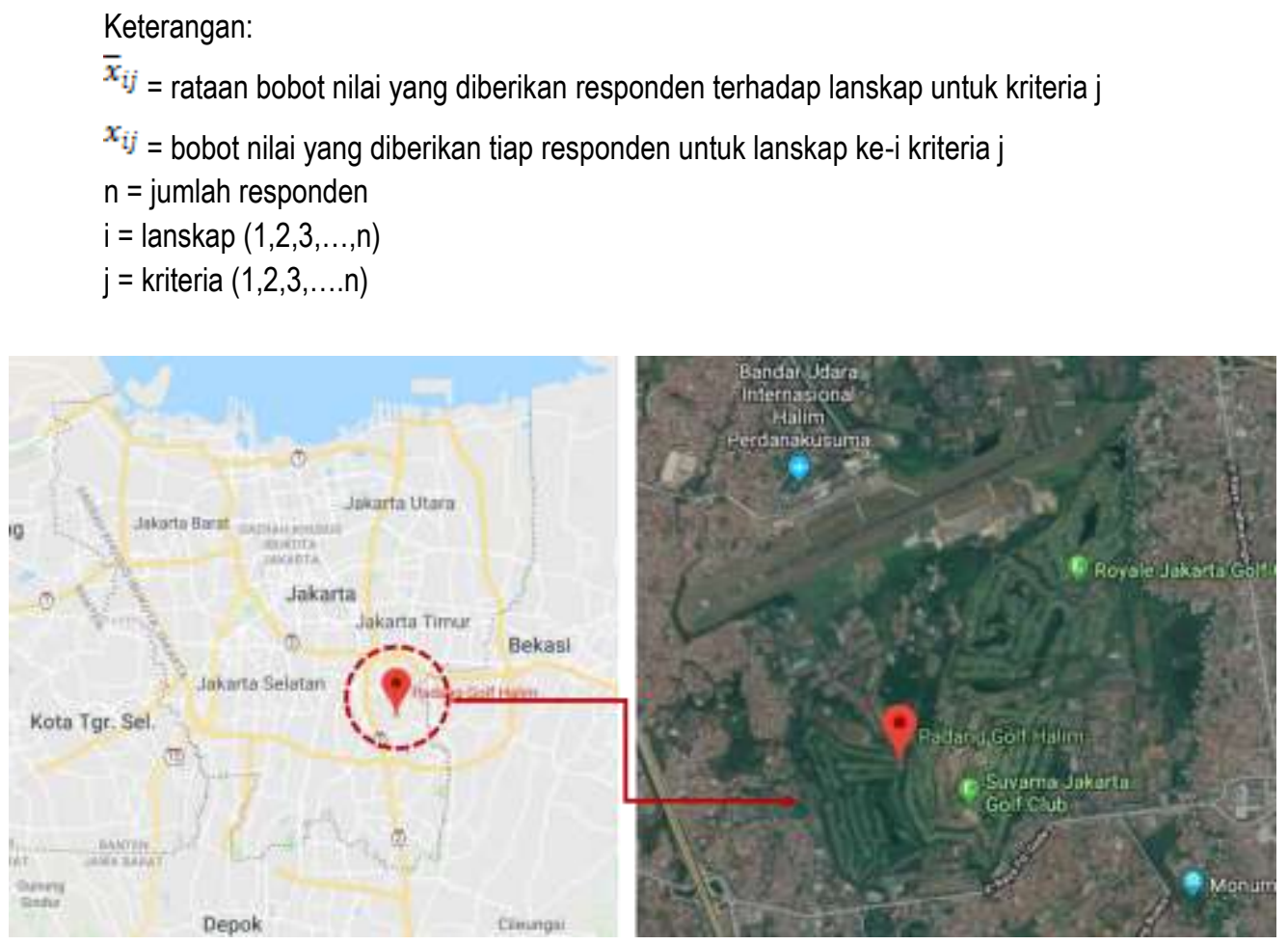

Gambar 1. Peta Lokasi Penelitian 

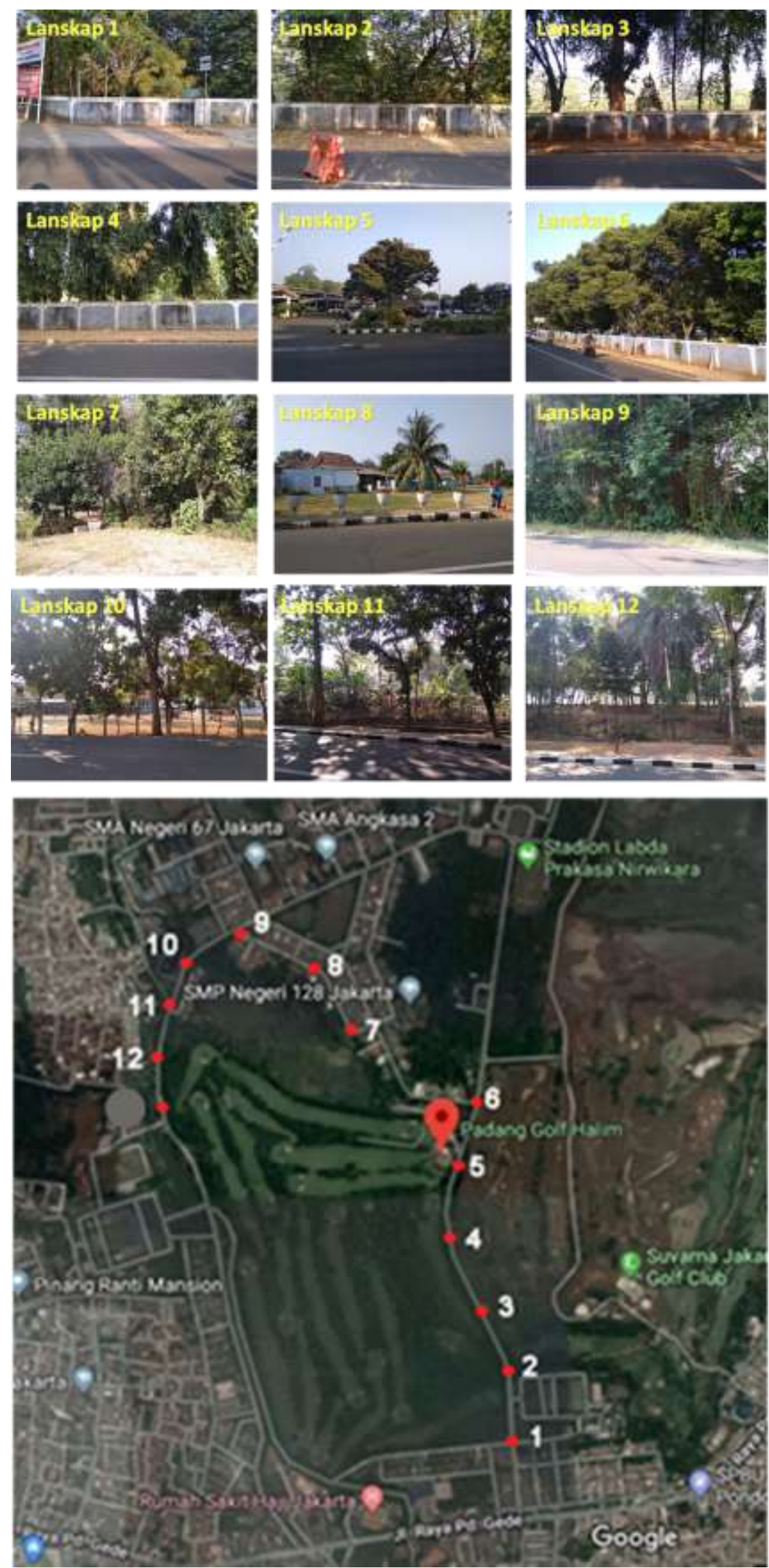

Gambar 2. Titik Sebaran Lanskap 


\section{Hasil dan Pembahasan}

\subsection{Kondisi umum}

PGH berada di Jalan Squadron, Kompleks TNI-AU Halim Perdanakusuma, Kelurahan Halim Perdanakusuma, Kecamatan Makasar, Jakarta Timur. PGH terdiri atas PGH I dan PGH II pada lokasi yang sama. PGH memiliki luas 148 ha dengan luas area permainan 52 ha (PGH I), 87 ha (PGH II), dan 3,8 ha (driving range) (Handy, 2013). Padang golf ini dimiliki oleh Yayasan Adi Upaya (Yasau). Berdasarkan struktur organisasinya, PGH dipimpin oleh general manager yang membawahi manajer umum, operasi, keuangan, PGH I, PGH II, dan DRPGH. Pimpinan dari struktur organisasi PGH adalah purnawirawan TNI-AU.

\subsection{Nilai keindahan}

Hasil yang diperoleh dari analisis SBE, hutan kota berbentuk lapangan golf secara umum memiliki nilai estetik (Gambar 3). Hanya terdapat satu titik yang dianggap tidak estetik oleh responden karena memiliki nilai SBE <20. Masyarakat cenderung kurang melihat nilai estetika suatu hutan kota pada lapangan golf apabila terborder oleh tembok. Diduga keberadaan tembok dianggap sebagai elemen yang tidak sesuai. Lanskap dengan vegetasi yang tebal juga tidak menjamin akan meningkatkan kualitas visual hutan kota pada lapangan golf. Hal ini terlihat dari Nilai SBE beberapa lanskap dengan vegetasi yang minim seperti pada sampel Lanskap 5 dan Lanskap 8 memiliki nilai SBE >20 yang artinya kualitas visual dinilai sangat estetik.

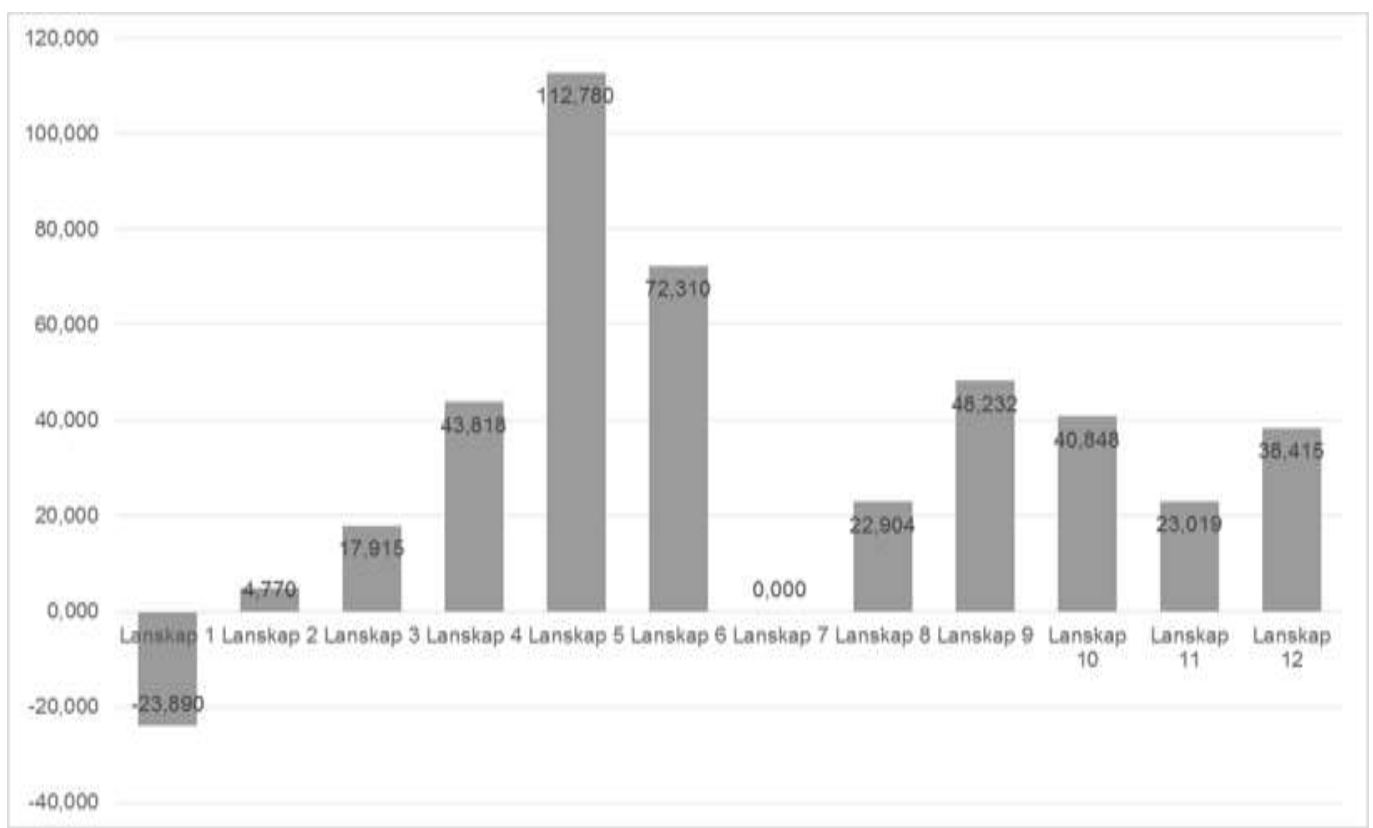

Gambar 3. Hasil Analisis SBE

\subsection{Kesan yang ditimbulkan}

Hasil analisis MDS dan SD dapat lebih menjabarkan kesan apa yang dirasakan responden (Gambar 4 dan Gambar 5). Berdasarkan hasil SBE, Lanskap 1 merupakan lanskap yang memiliki kualitas visual paling rendah yang apabila dilihat pada grafik MDS, lanskap ini lebih dipengaruhi oleh row 4 yang berdasarkan hasil SD mewakili kata sifat jelek. Lanskap-lanskap dengan kualitas visual yang tinggi berkumpul pada satu kelompok dan kesan yang timbulkan antara lain pada row 1 (bermanfaat), row 5 (sehat), dan row 3 (asri). Jadi dapat disimpulkan berdasarkan hasil analisis bahwa keberadaan hutan kota berbentuk lapangan golf, tidak hanya memiliki manfaat mengindahkan kawasan sekitar lapangan golf, tetapi juga menimbulkan kesan positif bagi masyarakat. Beberapa penelitian pernah melaporkan tentang hubungan kualitas visual dan masyarakat sebab masyarakat merupakan faktor utama dalam menjaga keberlanjutan suatu lanskap tak terkecuali dalam hal keberlanjutan estetika lanskap itu sendiri. Kesan yang ditimbulkan dalam suatu lanskap tidak selalu bernilai positif karena dipengaruhi oleh faktor penyusunnya (Senoglu et al., 2018; Arifin dan Masuda, 1998). 
Hasil SBE menunjukkan bahwa masyarakat paling menyukai visual Lanskap 5. Berdasarkan hasil MDS, faktor pembatasnya adalah row 3 (asri-gersang). Dari hasil analisis SD, arah grafik lanskap 5 adalah asri. Lanskap 5 secara struktur terdiri atas atas pohon dan semak yang tersusun rapi. Diduga kuat karena susunan pohon dan semak yang rapi menimbulkan kesan asri meskipun secara naungan tidak terlalu signifikan memberikan naungan. Hal ini sejalan dengan penelitian yang dilaporkan oleh Putra (2018) yang menyatakan bahwa desain lanskap yang ekologis dengan vegetasi yang rimbun cenderung memiliki nilai estetika yang rendah. Salah satu faktor yang mendasarinya adanya tren desain minimalis yang lebih digemari oleh masyarakat saat ini.

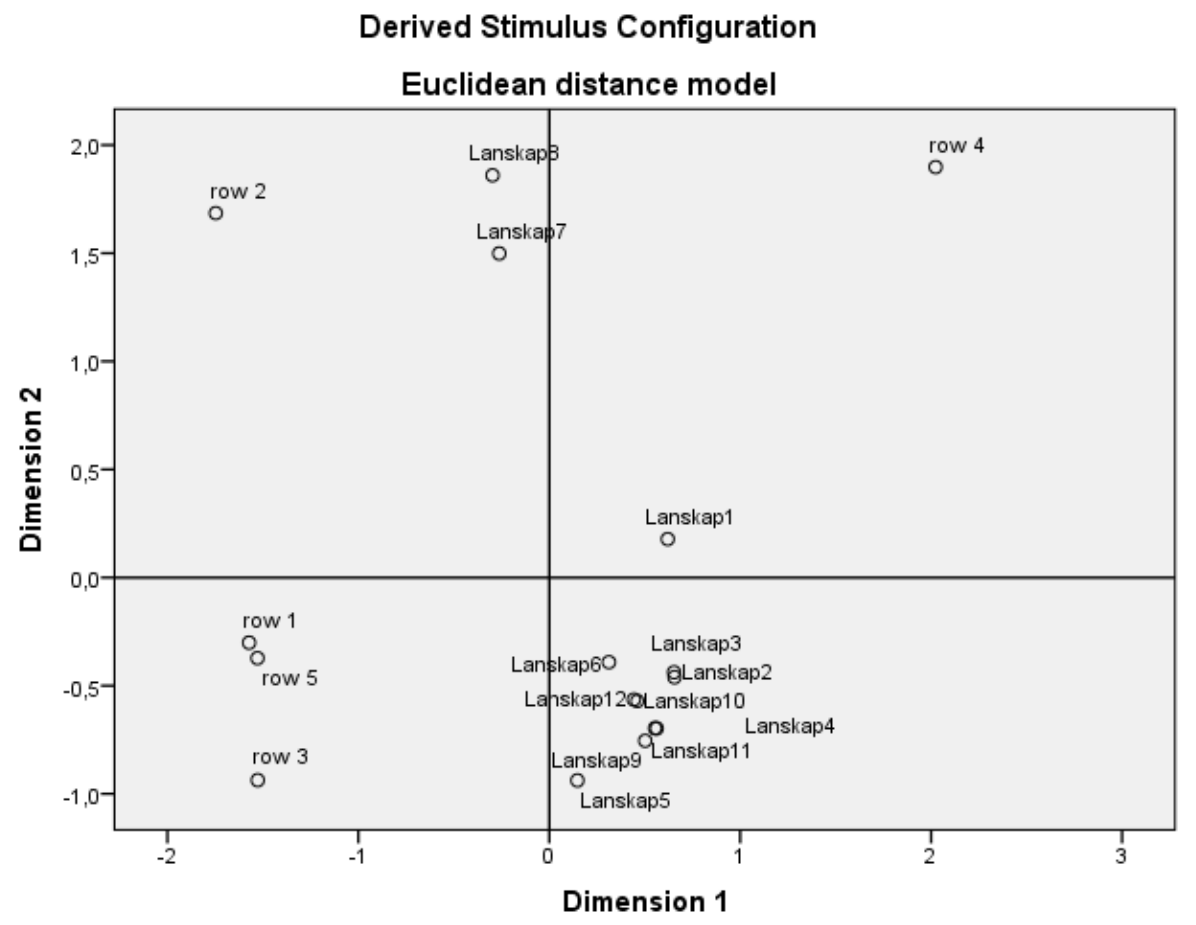

Gambar 4. Hasil Analisis MDS

Lanskap 1 merupakan visual lanskap yang paling rendah nilai SBE-nya, serupa dengan Lanskap 2 dan Lanskap 7. Berdasarkan struktur penyusun, pepohonan dalam ketiga lanskap tersebut terlihat rimbun. Berdasarkan hasil MDS, faktor pembatas Lanskap 1 adalah row 1 (bermanfaat-merugikan). Dari hasil analisis SD, arah grafik Lanskap 1 adalah netral yaitu tidak memberikan kesan bermanfaat ataupun merugikan. Diduga karena terdapat elemen lain seperti spanduk iklan, signage, dan pagar tembok, sehingga berpengaruh terhadap penilaian kualitas estetika. Sejalan dengan penelitian yang telah dilakukan Putra (2018) dan Wardiningsih et al. (2017), nilai SBE yang rendah dipengaruhi faktor elemen lanskap yang tidak sesuai penempatannya baik berupa hardscape maupun sofscape sehingga mengganggu kualitas pandangan. Faktor pembatas Lanskap 2 adalah row 5 (sehat-sakit) dengan arah grafik adalah sehat. Meskipun secara visual Lanskap 1 dan Lanskap 2 memiliki kemiripan struktur pohon dan terdapat elemen hardscape berupa pagar tembok, kedua lanskap tersebut memiliki perbedaan persepsi menurut responden. Lanskap 7 memiliki faktor pembatas row 2 (panas-sejuk) dengan arah grafik panas. Diduga karena adanya area terbuka pada bagian depan sehingga responden menilai Lanskap 7 memiliki kesan panas. Sejalan dengan penelitian sebelumnya yang menyatakan bahwa panjang gelombang cahaya tampak berkisar antara 400-700 nm akan menimbulkan kesan panas dan tidak disukai oleh responden dalam mengamati kualitas visual (Syahadat et al, 2019). 
Bagi sebagian besar masyarakat di Indonesia, hutan identik sebagai objek lanskap yang sakral, tertutup, dan harus dijaga, sehingga muncul tradisi menjaga hutan. Pernyataan ini didukung dengan adanya budaya lisan tentang sebuah larangan untuk memasuki, merusak, atau berbuat tidak pantas di sekitar hutan. Hal tersebut merupakan produk para leluhur yang melakukan budaya lisan secara turun temurun yang secara tak langsung melestarikan keberadaan hutan (Darmanto, 2009; Suryadarma, 2009; Balawa, 2010; Vansina, 2014). Jadi, bagi masyarakat Indonesia pada umumnya, lanskap-lanskap dengan kerapatan vegetasi yang tinggi, cenderung mendapatkan penilaian kesan yang cenderung menakutkan. Tak heran dari hasil penelitian ini, lanskap-lanskap dengan kerapatan vegetasi yang tinggi tidak memperoleh nilai kualitas visual yang tinggi. Hal ini sejalan dengan penelitian terdahulu yang dilakukan oleh Nuraini (2015) pada kajiannya mengenai pengelolaan hutan dan juga penelitian yang dilakukan Pratiwi et al., (2014) tentang perbedaan persepsi masyarakat Indonesia dan Jepang terhadap hutan. Untuk itu, dalam pengembangan hutan kota yang bernilai ekologis sekaligus bernilai estetik, perlu dilakukan pemilihan vegetasi serta penataan hutan kota yang tepat sehingga dapat menimbulkan kesan sebagai persepsi yang baik.

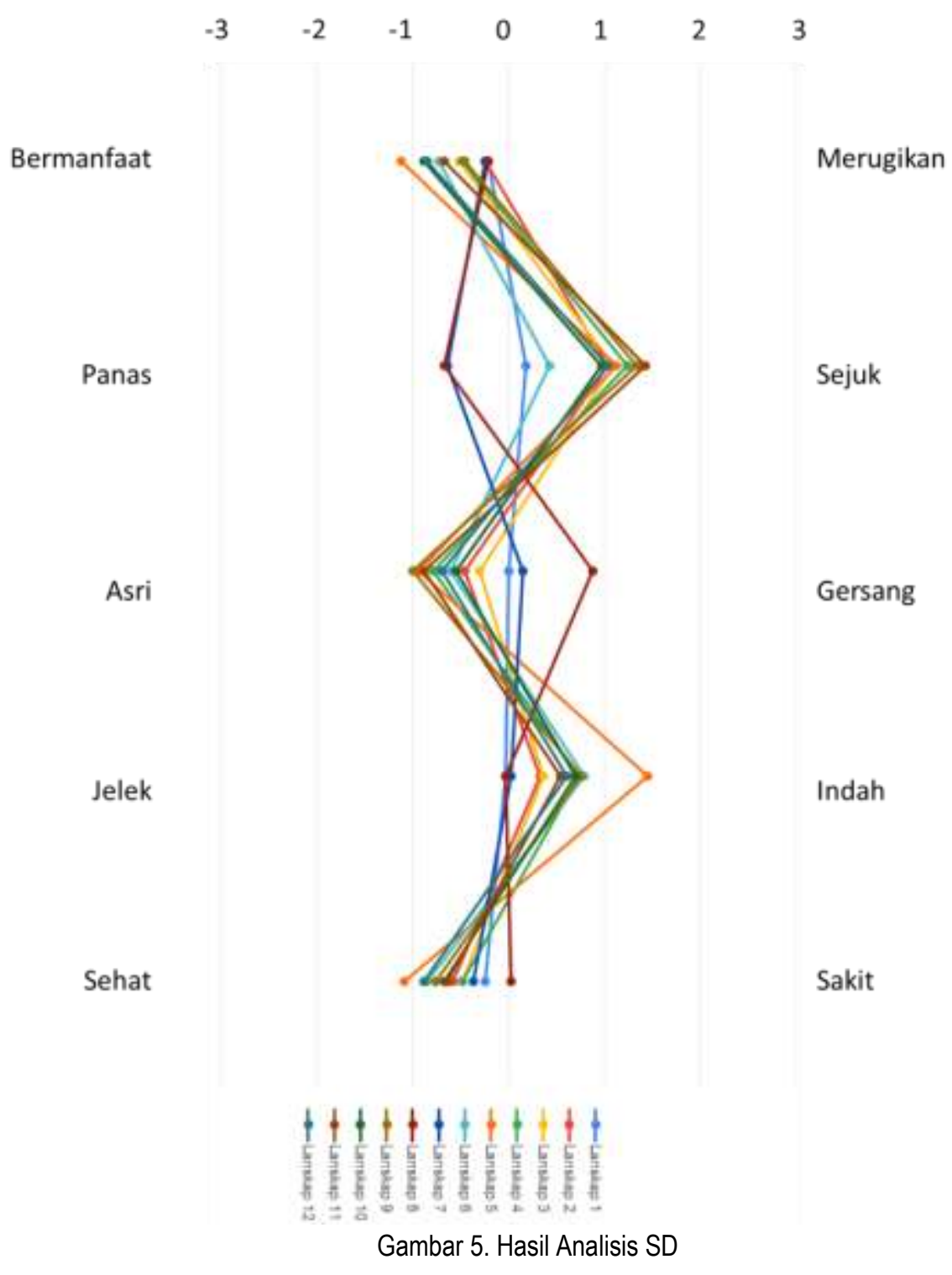

Secara umum dari hasil analisis SD dapat disimpulkan bahwa dari semua sampel titik visual yang diambil memberikan kesan sehat dan bermanfaat. Hal ini menunjukkan bahwa fungsi utama RTH berupa fungsi ekologis tercapai sejalan dengan Peraturan Menteri Pekerjaan Umum Nomor 05/PRT/M/2008, antara 
lain untuk pengatur iklim mikro, peneduh, dan penyerap polutan. Fungsi estetika hutan kota berupa keindahan lanskap memang bukan prioritas. Namun demikian, perlu dipertimbangkan penataan estetika hutan kota pada lanskap lapangan golf untuk semakin meningkatkan kenyamanan visual bagi pengguna/masyarakat. Hal ini didasarkan karena hutan kota merupakan tiruan struktur hutan alami sehingga diperlukan aspek visual dalam perancangannya.

\section{Simpulan}

Keberadaan hutan kota PGH berdasarkan hasil analisis SBE maupun SD secara umum memberikan nilai manfaat estetik. Fungsi utama hutan kota PGH sebagai objek yang bermanfaat dan sehat tercapai berdasarkan penilaian masyarakat. Adapun tipe hutan kota dengan penataan pohon dan semak yang tidak terlalu rimbun serta elemen yang sesuai lebih disukai oleh masyarakat. Untuk itu seleksi vegetasi dan penataan tetap diperlukan meskipun berada di luar hutan kota berbentuk lapangan golf, sehingga lanskap tetap dapat dirasakan manfaatnya secara langsung dan memberikan kesan yang baik.

\section{Ucapan Terima Kasih}

Artikel ini merupakan sebagian dari hasil penelitian berjudul Evaluasi Nilai Manfaat Hutan Kota pada Padang Golf Halim Jakarta Timur yang memperoleh dana hibah Penelitian Dosen Pemula (PDP) tahun pelaksanaan 2019 oleh Kemenristek Dikti. Untuk itu, penulis mengucapkan terima kasih kepada seluruh pihak yang berperan selama kegiatan berlangsung.

\section{Daftar Pustaka}

Arifin, N. H. S., \& Masuda, T. 1998. Visitors' jugments on the scenery of Ritsurin Garden. Journal of The Japanese Institute of Landscape Architecture, 61(2):259-262.

Balawa, L. O. 2010. Pomali: kajian aspek didaktis dalam budaya masyarakat berbahasa Ciacia di Kabupaten Buton. Kandai, 2(11):197-206.

Dahlan, E. N. 2004. Membangun kota kebun (garden city) bernuansa hutan kota. Penerbit IPB Press, Bogor.

Darmanto. 2009. Pandangan tentang hutan, tempat keramat dan perubahan sosial di Pulau Siberut, Sumatera Barat. In H. Soedjito, Y. Purwanto, \& E. Sukara (Eds). Situs Keramat Alami. Jakarta: Yayasan Obor Indonesia.

Dewi, E. R. 2014. Evaluasi pemahaman pengetahuan kualitas dan pemeliharaan lapangan golf pada departemen golf operasional Imperial Klub Golf di Lippo Village Tangerang. Jurnal OE, 6 (3):309326.

Dlukha, S., Wardiningsih, S., Febriani, Y., Syahadat, R. M., \& Putra, P. T. 2017. Pemeliharaan hazard di Padang Golf Matoa Nasional, Jakarta Selatan. Buana Sains, 17 (2):115-124

Handy, W. T. 2013. Pengelolaan pemeliharaan lanskap kawasan Padang Golf Halim Perdanakusuma, Jakarta Timur. Institut Pertanian Bogor, Bogor.

Irwan, Z. D. 1997. Tantangan lingkungan dan lansekap hutan kota. Penerbit PT Pustaka CIDESINDO, Jakarta.

Mattjik, N. A. 2010. Budi Daya Bunga Potong \& Tanaman Hias. IPB Press, Bogor.

Muplihudin, Putra, P. T., Syahadat, R. M., \& Radnawati D. 2019. Efektivitas kapasitas kerja dalam pengelolaan lanskap area permainan Emeralda Golf Club, Tapos, Depok. Jurnal Arsitektur Lansekap, 5(1):107-113.

Nuraini, C. 2015. Kearifan lingkungan dalam pengelolaan hutan, tanah dan sungai di Desa Singengu, Kecamatan Kotanopan, Kabupaten Mandailing Natal, Sumatera Utara. J. Manusia dan Lingkungan, 22(1):100-105.

Putra, P. T. 2018. Persepsi, preferensi dan perilaku masyarakat terhadap konsep ecodesign lanskap permukiman. Tesa Arsitektur, 16(1):20-29.

Pratiwi, P. I., Sulistyantara, B., Gunawan, A., \& Furuya, K. 2014. A comparative study on the perception of forest landscape using LIST method between university student of Japan and Indonesia. JMHT, 20(3):167-178. 
Senoglu, B., Oktay H. E., \& Kinoshita, I. Visitors' perception of high-rise building effect on the scenery of traditional gardens: a case study in Hama-rikyu Gardens, Tokyo. Civil Engineering and Architecture, 6(3):136-148.

Suryadarma, I. G. P. 2009. Kawasan sakral perspektif perlindungan keanekaragaman hayati. In H. Soedjito, Y. Purwanto, \& E. Sukara (Eds). Situs Keramat Alami. Jakarta: Yayasan Obor Indonesia.

Sukmawijaya, I. W. G. A., Astiningsih, A. A. M., \& Kohdrata, N. 2019. Konsep pertamanan lanskap berdasarkan karakteristik pertamanan Bali pada lanskap New Kuta Golf. Jurnal Arsitektur Lansekap, 5(1):1-8.

Syahadat, R. M., Putra, P. T., \& Patih, T. 2017. Meningkatkan Keindahan Arsitektural Jembatan Surya Lembayung Kebun Raya Bogor dengan Tanaman Lanskap. E-Jurnal Arsitektur Lansekap, 3(1):2332.

Syahadat, R. M., Putra, P. T., Patih, T, Thoifur, D. M., Nurhasanah, F., \& Saleh, I. 2019. Struktur jalan layang Provinsi DKI Jakarta: sebuah kajian evaluasi kualitas visual. J. Infras, 5(1):45-50.

Vansina, J. 2014. Tradisi lisan sebagai sejarah. Penerbit Ombak, Yogyakarta.

Wardiningsih, S., Syafruddin, A., Syahadat, R. M., \& Putra, P. T. 2017. Kajian pencirian visual Kota Batu di Malang. Jurnal SCALE, 5(1):66-75. 